\title{
Demand of eLearning for Professional Education and Learners’ Preparation: Bangladesh Perspective
}

\author{
doi:10.3991/ijet.v5i1.1130 \\ A.K.M.I. Khalid \\ Bangladesh Open University, Gazipur, Bangladesh,
}

\begin{abstract}
This paper demonstrates the demand of elearning that needs to cope with and possible technology introduction through Bangladesh Open University as a lone government agency of distance education in Bangladesh for its learners who are doing Commonwealth Executive MBA (CEMBA)/Commonwealth Executive MPA (CEMPA) offered in cooperation with Commonwealth of Learning (COL) and MBA program of its own. Web based learning or eLearning is a new genre for providing services in the arena of education. Though in most developed countries such USA, Canada, UK, web based learning becomes popular to learners of their country, that is a very new to a third country like Bangladesh. Students of Bangladesh are also partaking courses through online programmes offered by those developed countries. These courses are expensive too, so it is necessary to establish our own elearning system in Bangladesh. As the demand of training and education is huge in Bangladesh, it is necessary to adapt the mobile and flexible system. Keeping the eye on view, a survey was conducted among the learners of those professional academic programmes. The informants were selected both from the capital city of Bangladesh as well as divisional cities and district town. The survey demonstrates that this technology can be appropriately used to meet the demands of the professional programmes. However, this survey also shows that the professional programmes require careful planning and sound technological infrastructures. The study will clarify how far prospective learners have the appreciation of the technology and how the learners have comparatively more preparation to participate in an eLearning programme rather than the organizations. The survey also focuses the primary and secondary education through collected data from websites of Bangladeshi government and private organization.
\end{abstract}

Index Terms-distance education, mobile and flexible system, technological infrastructures, third country.

\section{INTRODUCTION}

The success of graphical user interface (GUI) in computer technology, the ease of using mobile devices, the speed of Internet and the wide acceptance of distance learning are some major components which are responsible for introducing elearning. The important features of the system are that it saves traveling cost, accommodation cost and it offers flexibility and time-saving (Horton, 2000). Even there is flexibility in the use of technology for elearning. If we look into the definition as 'e-learning' is defined by the New Zealand Ministry of Education (2004, 3 ) as "learning that is enabled or supported by the use of digital tools and content. It typically involves some form of interactivity, which may include online interaction between the learner and their teacher or peers. E-learning opportunities are usually accessed via the internet, though other technologies such as CD-ROM are also used in elearning." As the professional life of people nowadays is getting busy, elearning shows positive aspects for learning. If professional people need to participate in education or in training, they can plan their learning at their own time and pace. The demand for education is high, the opportunity for participating in a course is less and expensive in a country like Bangladesh, elearning is a most appropriate approach for meeting the huge demand if the learners has the infrastructure and technical capacity to do so. Keeping those facilities of the system, I started a survey and research on the demand of elearning to the learners who are currently studying MBA, CEMBA/CEMPA programmes at Bangladesh Open University.

\section{NECESSITIES OF THE RESEARCH}

BOU as a university of distance education is delivering academic programme since 1992 and this university understands the need for adaptation of technology based education. So this university is preparing its manpower for the technology by conducting training on Authoring Tools which was conducted by Commonwealth Educational Media Centre for Asia and the programme had been funded by UNESCO and they are participating on wikieducator online workshops, some other people had got training on eLearning Technology from ADMTC, University of Colombo funded by JICA. So the university is going towards equipping its manpower. However, the university should also know if the university starts any formal academic programme online, the programme would be accepted by the people of the country and whether the people or prospective learners have appropriate computer technological knowledge whether they have the infrastructure to be able to attend elearning programme or whether they have mental capacity, motivation and patience to learn together or alone. Thus, this type of research is very important before starting an elearning programme by any institute or university because starting a technology based education involves cost more than traditional education. This costing and technology selection requires appropriate planning and careful shaping of the programme. 


\section{DEMAND OF PROFESSIONAL EDUCATION IN BANGLADESH}

If you look at the newspaper for executive jobs like front desk coordinator, floor manager, public relation officer, marketing or operation manager, every three advertisement out of five you would get companies require a person who has a first degree along with professional education or diploma like personnel management, MBA, hospitality or public relationship training etc. As Bangladesh is growing in garments, textile, leather and agriculture sectors and contributing significantly to the National GDP, so the number of govt. and non-govt. university is increasing. Currently, there are 28 govt. university and 56 non-govt. university in Bangladesh. However, the demand can not be met as expected because professional people do not have opportunity for participating in a regular professional development academic programme as these people have time constraints. Bangladesh Open University is currently offering professional programme targeting those people successfully but there is also limitation for the university since there is seat limitation. This university cannot offer admission to all applicants who seek to study in the university.

\section{PROFESSIONAL EdUCATION AT BOU}

BOU has developed its curriculum in open and distance learning which requires to be modified as elearning materials for which its manpower is getting trained as I already mentioned earlier. BOU has been offering Master of Business Administration (MBA), Commonwealth Executive Master of Business Administration (CEMBA)/Commonwealth Executive Master of Public Administration (CEMPA), Bachelor of Agriculture Education (B.Ag.Ed), Master of Education(M.Ed), Bachelor of Education (B.Ed), Development of Youth Programme (DYDP) and other programmes. These programmes directly are related to the self development and professional development.

\section{RESEARCH METHODOLOGY}

I selected CEMBA/CEMPA, MBA students of School of Business of BOU for the research. I developed questionnaire which contained structured questions and I also arranged discussion among the learners and I took their interview regarding the elearning about their interest in online education. I divided the questionnaire into six sections which were 1. Access to Computer and Technology 2. Basic Skills for Computer 3. Technology Adaptation Skill 4. Personal Enthusiasm and Motivation 5. Expertise in Using Online Audio/Video Media 6. Requirement for Success. In total, all the sections contained 32 questions. All the questions emphasized personal aspects of the informants. There was a comment option "Any Comment on Your Preparation for eLearning or on Web Base Learning”. Other few questions like Name, Age, Sex, personal email address were there in the questionnaire. The number of informants who took effort to participate in the research is 132 .

\section{PRESENTATION OF DATA}

As per the questionnaire, I would present the data using six tables and though the tabular data does not attract much the readers and the audience, I require to provide data in tabular format because of the type of data though it may not be convenient to have more attention from the readers and audience. The learners of the programmes are usually from good academic background and most of them have jobs to work in the office. They already completed first degree and they are studying at BOU on holiday. So they have computers or access to computers, they have comparatively new computer operating systems like Windows XP/ Windows Vista, the computer has Word Processor, Spreadsheet, Adode Reader/Writer Software installed and they have access Internet at their computer or have access to Internet System. Almost the questions of the questionnaire start with a pronoun "I" meaning the question emphasizes the informant himself/herself because the informant is giving personal opinion, personal data about skill, experience and the data is solely related to the informant. The following table I describes the data:

TABLE I.

ACCESS TO COMPUTER AND TECHNOLOGY

\begin{tabular}{|l|l|l|}
\hline \multicolumn{1}{|c|}{ Questions } & Available & \multicolumn{1}{|c|}{$\begin{array}{c}\text { Not Avail- } \\
\text { able }\end{array}$} \\
\hline $\begin{array}{l}\text { I have a computer or have an } \\
\text { access to computer }\end{array}$ & $88 \%$ & $12 \%$ \\
\hline $\begin{array}{l}\text { I have a new computer with } \\
\text { enough RAM, Hard Disk, CD } \\
\text { ROM, Speakers etc. }\end{array}$ & $82 \%$ & $18 \%$ \\
\hline $\begin{array}{l}\text { I have Internet access to my com- } \\
\text { puter or have access to Internet }\end{array}$ & $74 \%$ & $26 \%$ \\
\hline $\begin{array}{l}\text { I have software like word proces- } \\
\text { sor, spreadsheet, Adobe Acrobat } \\
\text { Reader/Writer etc. in my com- } \\
\text { puter }\end{array}$ & $89 \%$ & $11 \%$ \\
\hline $\begin{array}{l}\text { I have fairly new operating sys- } \\
\text { tem like Windows XP/Vista etc. }\end{array}$ & $85 \%$ & $15 \%$ \\
\hline
\end{tabular}

I tried to find out the basic skills for computer of the learners who would participate in elearning programme. I completed these part of the questionnaire which mentioned about their capacity to run computer from start menu, their ability to create a file, open, delete or recover a file, their knowledge about printing a file and using cut, copy options of a file. The Table II would explain the learners' basic skill:

TABLE II.

BASIC SKILLS FOR COMPUTER

\begin{tabular}{|l|c|c|}
\hline \multicolumn{1}{|c|}{ Questions } & Available & $\begin{array}{c}\text { Not Avail- } \\
\text { able }\end{array}$ \\
\hline $\begin{array}{l}\text { I can run a computer application } \\
\text { from the desktop or through the } \\
\text { Start menu }\end{array}$ & $94 \%$ & $6 \%$ \\
\hline $\begin{array}{l}\text { I can create a new file, delete a } \\
\text { file and recover a file }\end{array}$ & $92 \%$ & $8 \%$ \\
\hline $\begin{array}{l}\text { I can open a file, and use the } \\
\text { save and save as options }\end{array}$ & $92 \%$ & $8 \%$ \\
\hline $\begin{array}{l}\text { I can see print preview, do page } \\
\text { setup, print a file }\end{array}$ & $93 \%$ & $7 \%$ \\
\hline $\begin{array}{l}\text { I can use cut, copy and paste } \\
\text { options within a file, between } \\
\text { files }\end{array}$ & $92 \%$ & $8 \%$ \\
\hline
\end{tabular}

I approached the 132 informants and asked about their technology adaptation skill highlighting their skill about email, Internet, messenger services, online correspondences etc. I provided explanation, they asked about the questions, I as a researcher listened to their ideas and I tried to find their confidence in participating online academic programme and talked to them about their prospect in education and training through an online programme. 
TABLE III.

TECHNOLOGY ADAPTATION SKILL

\begin{tabular}{|l|c|c|}
\hline \multicolumn{1}{|c|}{ Questions } & Available & $\begin{array}{c}\text { Not } \\
\text { Avaiable }\end{array}$ \\
\hline $\begin{array}{l}\text { I have basic skills for finding informa- } \\
\text { tion using search engine like google, } \\
\text { yahoo, msn etc. }\end{array}$ & $80 \%$ & $20 \%$ \\
\hline I can send and receive emails & $84 \%$ & $16 \%$ \\
\hline $\begin{array}{l}\text { I can use options like Reply, Reply to } \\
\text { All and Forward emails }\end{array}$ & $86 \%$ & $14 \%$ \\
\hline I can send emails with attach files & $81 \%$ & $19 \%$ \\
\hline $\begin{array}{l}\text { I can use address book of my email } \\
\text { account }\end{array}$ & $75 \%$ & $25 \%$ \\
\hline $\begin{array}{l}\text { I can participate in a course using a } \\
\text { computer }\end{array}$ & $82 \%$ & $18 \%$ \\
\hline $\begin{array}{l}\text { I can communicate with others using } \\
\text { emails chat etc. for a course }\end{array}$ & $75 \%$ & $25 \%$ \\
\hline $\begin{array}{l}\text { I can express myself clearly to others } \\
\text { through my writing }\end{array}$ & $82 \%$ & $18 \%$ \\
\hline $\begin{array}{l}\text { I can complete assignment with learn- } \\
\text { ers who are staying in different time } \\
\text { zone }\end{array}$ & $64 \%$ & $36 \%$ \\
\hline $\begin{array}{l}\text { I can maintain timely correspondence } \\
\text { with other learners and instructors }\end{array}$ & $82 \%$ & $18 \%$ \\
\hline $\begin{array}{l}\text { Using electronic technologies like } \\
\text { email, chat, I can be able to ask ques- } \\
\text { tions and clear comments }\end{array}$ & $76 \%$ & $24 \%$ \\
\hline
\end{tabular}

I discussed about their personal enthusiasm and motivation in participating an online programme since the learning system is mostly depending on personal ability and initiative to learn new things and new approaches. These questions targeting personal trust on themselves like whether they can study alone, studying from CD whether Internet is not available or whether they can study while distraction at home and office. I collected data from six visits from difference regional centre (RRC) of Bangladesh, so I had the opportunity to spend sometimes concentrating the questions and approach individually.

TABLE IV.

PERSONAL ENTHUSIASM AND MOTIVATION

\begin{tabular}{|l|c|c|}
\hline \multicolumn{1}{|c|}{ Questions } & Available & $\begin{array}{c}\text { Not } \\
\text { Avaiable }\end{array}$ \\
\hline $\begin{array}{l}\text { I can study alone even if the instructor or } \\
\text { other learners are not online }\end{array}$ & $73 \%$ & $27 \%$ \\
\hline $\begin{array}{l}\text { I am able to continue and complete my } \\
\text { study from my CD ROM or download } \\
\text { files from Local Network even if there is } \\
\text { online disruption }\end{array}$ & $70 \%$ & $30 \%$ \\
\hline $\begin{array}{l}\text { I can study even if there is distraction at } \\
\text { home and office }\end{array}$ & $69 \%$ & $31 \%$ \\
\hline
\end{tabular}

I surveyed the students' expertise in using online media (audio/video) and I found the following data (table V) from them which also showed that the positive trend of their technological knowledge at using the online audio/video programmes. The questions were asked highlighting their capacity of understanding online audio/video lectures, their ability to take notes from those lectures, their competence to relate printed material with the audio/video lectures, their skill in carrying discussion online and in communicating several users at a time on different topics.

I reviewed students' requirement for success if they participate in an elearning programme offered by Bangladesh Open University. It is very much related to their personal necessities while they study a programme under online system. These questions were whether they require regular contact of their instructors, whether they want administrative support to keep themselves online, or they need knowledge about email, internet chat, online reading before they start a programme in participating an online programme (table VI).

TABLE V

EXPERTISE IN USING ONLINE MEDIA (AUDIO/VIDEO)

\begin{tabular}{|l|c|c|}
\hline \multicolumn{1}{|c|}{ Questions } & Available & $\begin{array}{c}\text { Not } \\
\text { Available }\end{array}$ \\
\hline $\begin{array}{l}\text { I am able to understand online Au- } \\
\text { dio/Video Lectures }\end{array}$ & $82 \%$ & $18 \%$ \\
\hline $\begin{array}{l}\text { I am able to take notes from online Au- } \\
\text { dio/Video Lectures. }\end{array}$ & $72 \%$ & $28 \%$ \\
\hline $\begin{array}{l}\text { I can relate printed or online study mate- } \\
\text { rials with Online Audio or Video Lec- } \\
\text { tures }\end{array}$ & $73 \%$ & $27 \%$ \\
\hline $\begin{array}{l}\text { I can carry on a discussion focusing a } \\
\text { particular topic using Internet like Chat, } \\
\text { Instant Message }\end{array}$ & $67 \%$ & $33 \%$ \\
\hline $\begin{array}{l}\text { I can comfortably talk to several users } \\
\text { discussing different topics at a time } \\
\text { using Internet like Chat, Instant Message }\end{array}$ & $59 \%$ & $41 \%$ \\
\hline
\end{tabular}

TABLE VI.

MY REQUIREMENT FOR SUCCESS

\begin{tabular}{|l|c|c|}
\hline \multicolumn{1}{|c|}{ Questions } & Required & $\begin{array}{c}\text { Not Re- } \\
\text { quired }\end{array}$ \\
\hline $\begin{array}{l}\text { I need to contact my instructors regularly } \\
\text { to complete an online programme }\end{array}$ & $51 \%$ & $49 \%$ \\
\hline $\begin{array}{l}\text { I require administrative support to be } \\
\text { successful in completing an online pro- } \\
\text { gramme }\end{array}$ & $68 \%$ & $32 \%$ \\
\hline $\begin{array}{l}\text { I need prior expertise with email, Internet } \\
\text { Chat, Online Reading etc. to be success- } \\
\text { ful in completing an online course. }\end{array}$ & $13 \%$ & $87 \%$ \\
\hline
\end{tabular}

\section{PERSPECTIVE OF INTRODUCING ELEARNING}

Though I worked on students of MBA, CEMPA/CEMBA of Bangladesh Open University, the above six tables, it is obvious that the required technological devices, software and technological skills are available to the students. In Bangladesh, 67\% people are educated and who completed primary and secondary education and $43.1 \%$ people whose age is more than 15 years entered higher secondary or tertiary education. The population of our country is 135.2 million 2004 million according to the consensus of 2004. 70 million people can be targeted by a institute who has an aim to delivery education using elearning technologies. The poverty is also well known to all over the world for its size of poor people. If $40 \%$ people live over poverty line and have a solvent financial power. The $40 \%$ means 60 million people have capacity and availability to participate in an elearning programme. The private sector for employment is also growing. Garments, Textile, leather, agriculture are some big sectors where Bangladesh are growing fast and trying to meet our own requirement. Where people needs updated training and professional education. So, the prospect of introducing elearning in Bangladesh is very hopeful. Only the country needs dedicated institutes, private, public institutional endeavor to careful planning for long term and short term programming. However, because of adverse natural climate and every year flood cause 


\section{DISCUSSION ON THE INFORMATION}

I had an opportunity to approach the informants with structured questionnaire and discuss with them individually and in group. The informants of MBA programme who completed their first degree in some academic subject come complete their first master programme or their second master programme and working in some government, private office. However, there were some educated unemployed people too. However, they know where to go with the programme and why they are here. So they are mature people and know why they are studying here. I discussed with them at the classroom while the class teacher handed over the class for the time being or outside the classroom in a very informal way to know about their mental shape or attitude towards web based learning or computer based learning like CBT. The learners said that they needed this new way of learning system because they worked in an office or did business. So each Friday is very important to meet their personal requirement, and the 20 classes are not enough to complete a module whereas if they have an opportunity to access to the learning module or to talk to a teacher while they feel it to do so. Meaning only blending system in Open and Distance Learning (ODL) is not enough, the distance learning should be added with the Internet technology based facilities. Some other learners were saying that they needed this web based learning because they could have studied at home and since there would be an online teacher for all the time, they can ask the teacher. Otherwise, they can also look at the recorded programmes if you feel to have a lesson using audio/video recorded classes which may be available through Internet or every student would be provided with some module based CDs. So, the flexibility in learning would be properly introduced to the students who are doing private jobs and they don't have much extra time to manage time for studies, though for continuous skill development it is necessary to participate in a course which is necessary for the personal development. Some informants put forward the example of the wide acceptance of mobile telecommunication. Once there was a need for telecommunication which was not properly taken care by the government sector of Bangladesh and the place was taken by private and foreign entrepreneurs who found unprecedented success in Bangladesh, a third country. So the informants felt there was opportunity waiting for those who start elearning or web based learning.

\section{CONTRIBUtion to MillenNiUm DEVElopment GOALS (MDG)}

The technology base education system can contribute to the targets of MDG because the system can cover more than thousand people in a platform where there would people who have resources or who may live under poverty line meaning an abject poverty. If the country wish to reach the target of MDG like Development and Poverty Eradication, education for all is an effective tool to address the situation prevailed in Bangladesh. The country should introduce technology based education like community radio, CBT learning, web based learning. Though the technology based education requires extra money to procure the technical tools, the technology can address more pupils at a time than a traditional classroom. For example, in a primary school, where a computer and a multimedia projector can be used to address a classroom which can be a formal education centre or non formal education. Though the research data primarily concentrate on the students of graduate students who are studying in a distance method, any form of elearning like web base learning, CBT, could be used in Bangladesh since the technology is available today though it does not reach some $43 \%$ people of the country. However, it can reach other $57 \%$ people whose number is almost 67 million people. Once the system is introduced to the people, it would attract and invent new ways to approach the people.

\section{Conclusion}

Thus the study reflects that the Bangladeshi people demand the web base learning and they have potential efficiency to admit and to continue an elearning programme. It is also reflected that the web based learning system is a new genre in Bangladesh which needs to launch by a university like Bangladesh Open University or any other private institute or a foreign entrepreneurs who have experience in distance learning and have the technological basement to start web base education. Since this study mainly focuses on the existing students of Bangladesh Open University and the majority of students have technology, skill and eagerness to participate in an academic programme through elearning system, BOU can start developing elearning module and start online education for MBA, CEMBA/CEMPA students, or any other local or foreign institute can establish an elearning centre. The data of this research can positively ensure that the learners are ready to accept the new method of education, now it is only the institutional preparation and requirement to avail the opportunity.

\section{ACKNOWLEDGMENT}

I would like to thank the Bangladesh Open University authority to allocate a fund to conduct the research on "Learners' Readiness for Participating an eLearning Programme: Bangladesh Perspective”.

\section{REFERENCES}

[1] Horton, William, Designing Web-Based Training, How to Teach Anyone Anything Anywhere Anytime, 2000, John Wiley \& Sons, Inc. New York, USA

[2] Nichols, M., \& Anderson, B. (2005). Strategic e-learning implementation. Educational Technology \& Society, 8 (4), 1-8.

[3] http://www.webopedia.com/quick ref/mobile_OS.asp

[4] http://en.wikipedia.org/wiki/Metaphor Computer Systems

[5] http://www.computerhope.com/os.htm

[6] http://www.eng.wayne.edu

[7] http://derekstockley.com.au/elearning-definition.html

[8] http://en.wikipedia.org/wiki/Higher_Education_in_Bangladesh

[9] http://www.moedu.gov.bd/bangladesh.htm

[10] http://en.wikipedia.org/wiki/Millennium Development_Goals

[11] http://en.wikipedia.org/wiki/United_Nations_Millennium_Declara tion

[12] http://www.bdix.net/sdnbd_org/world_env_day/2001/sdnpweb/sdi international day/literacy/2003/statestics.htm

\section{AUTHOR}

Khalid, A.K.M. Iftekhar is working as Assistant Director (Training) at Training and Research Section in Bangladesh Open University, Gazipur, Bangladesh.

Submitted October $31^{\text {st }}$, 2009. Published as resubmitted by the author February 11, 2010. 